\title{
EVALUATION OF POLLUTION LEVEL CAUSED BY DOMESTIC EFLU- ENT IN THE POTY RIVER - TERESINA PI - BRAZIL
}

\author{
Izabele Folha Damasceno, Vivane Lopes Leal, Ronaldo Cunha Coelho, Carla Verônica Rodarte de Moura e Ed- \\ milson Miranda de Moura*
}

\author{
Departamento de Química, Universidade Federal do Piauí, Campus da Ininga, 64049-550 Teresina-PI, Brasil \\ *mmoura@ufpi.edu.br
}

This article reports on the level of contamination of effluents, sediments and water in the Poty River, within the city of Teresina. The samples were collected in the months of September 2009, December 2009 and March 2010. The results of some physico-chemical parameters investigated, as well as the concentrations of lead, copper and nickel found in the river water samples showed that the body of water in the Poty River is unsuitable for use in various activities. These activities include direct recreational usage and primary irrigation of vegetables that are eaten raw as well as fruits that are eaten without removing films, among others.

Keywords: Poty River, pollution of the effluent; water quality

\section{Introduction}

Waterways pollution has worsened terribly after the construction of domestic sanitary sewage plants that dump its polluted contents into the rivers, sea, etc. [1] The accumulation of city-generated solid waste that is washed away by the rain can also cause pollution in water bodies. The poor quality of urban sanitation and lack of public awareness have brought great damage to storm water quality [2-5]

Metals differ from toxic organic compounds in that they are absolutely non-degradable, so they may accumulate in the environment where their toxicity is manifested. Many studies [2-5] have been developed in order to quantify metals in river water and these studies have shown that the concentrations of some metals are very high, and therefore can cause serious environmental problems regarding water and sediments [5,10-14]. The main sources of contamination from these rivers are from various human activities [2-4]

The Poty river, the subject of this study, has a semi-perennial watercourse that runs $550 \mathrm{~km}$ long. It is one of the most predominant of Parnaiba, with its origin in Joaninha Serra, in the state of Ceará. Its basin is $49,800 \mathrm{~km}^{2}$, and reaches 27 municipalities, eleven of those being in the state of Ceará and 16 in Piauí. Its waters serve a variety of purposes such as public water supply, watering livestock, irrigation of agricultural crops, conservation of flora and fauna, recreation and lounge [15].

The urban area of the Poty River in Teresina receives in its bed twenty-three sewers without any pre-treatment. Teresina has more than eight hundred and six thousand inhabitants and only $13 \%$ of the population has access to a sewage system. Moreover, this population often has the largest collective network but the parent company of water and sewerage services of Teresina (Agua e Esgoto do Piauí/SA - AGESPISA) did not make the connection to the network of people's homes [15].

The economic and social development of cities or countries is based on the availability of water quality and in the ability to conserve and protect watersheds. The quantification of the pollutant load of a water body is the key of to any management that focuses on the conservation and sustainable use of water [16]. This study aimed to analyze the level of pollution in the urban area of the Poty River in Teresina. The results were analyzed using multivariate tools (Principal Component Analysis-PCA) which allowed an assessment of the environmental impact caused by waste disposed in the bed of the river without any pretreatment. 


\section{Experimental}

\section{Solutions and reagents}

The cleaning material used was initially performed with alkaline detergent solution, then washed with distilled water and left for $24 \mathrm{~h}$ in $\mathrm{HNO}_{3}$ solution $(10 \%(\mathrm{v} / \mathrm{v})$. Finally, they were rinsed with deionized water and dried.

All solutions were prepared with reagents of analytical grade (Merck, Aldrich, Fluka and Vetec) and deionized water (resistivity $18 \mathrm{M} \Omega \mathrm{cm}^{-1}$ ) purified through the Milli-Q system (Millipore, Bedford, MA, USA).

As reference solutions, we used stock solutions of $1000 \mathrm{mg} \mathrm{L}^{-1}$ in acid $\left(\mathrm{HNO}_{3}\right.$ ) to $\mathrm{Cr}$ (lot in 14618/1), $\mathrm{Cu}$ (lot 207071/1), Ni (lot 207322 ) and $\mathrm{Pb}$ (lot 207233) and $\mathrm{Pb}$ (lot 671063), all obtained from Fluka.

The analytical curves of metals were obtained using the diluted stock solutions prepared in advance. The calibration curves were constructed using six different concentrations.

\section{Equipment}

Dissolved oxygen and temperature were measured using a digital oximeter Alfakit model AT 140. The $\mathrm{pH}$ and conductivity measurements were carried out using, Instrutherm conductivity, model CD-830 and Tecnal pHmeter, model Tec-3MP.

Nitrite and nitrate were measured by colorimetric methods described in Standard Methods for the Examination of Water and Wastewater [17] using Hitachi molecular absorption spectrophotometer, model U3000.

Metals concentrations $\mathrm{Pb}, \mathrm{Cr}, \mathrm{Ni}$ and $\mathrm{Cu}$, were determined using an atomic absorption spectrometometer, model SpectraAA 220FS Varian GTA 100, equipped with background correction, deuterium lamp and operating with cathode current hollow, pass spectral band and the following wavelengths: $5.0 \mathrm{~mA}, 1.0$ and 217.0 $\mathrm{nm}(\mathrm{Pb}), 7.0 \mathrm{~mA}, 0.2$ and $347.9 \mathrm{~nm}(\mathrm{Cr}), 4.0 \mathrm{~mA}, 0.2$ and $232.0 \mathrm{~nm}(\mathrm{Ni})$ and $4.0 \mathrm{~mA}, 0.5$ and $324.7 \mathrm{~nm}(\mathrm{Cu})$.

\section{Procedure of sampling}

Samples were collected in the Poty river in the urban area of Teresina (city founded in 1852 and -located in the central north of Piaui state and a mid-north of the Brazilian northeast, south elevation with $05^{\prime} 05^{\prime}$ " and longitude 1242 '48 42'. Samples were collected in September 2009 (mostly dry river), December 2009 (early rains) and March 2010 (full river). The sampling sites (Table 1) were defined according to the release of effluents into the Poty River, except for the first point (P1) where there is no effluent discharge.

The P1 point was chosen as the beginning of the urban perimeter, ie, due to having no contamination caused by effluent discharge.

In the urban area of Teresina were chosen eight collection points (Fig. 1) for sampling of water and sediments and five collection points for sampling of effluent.

The sampling sites for water and sediment samples were selected as follows: five samples (points) were collected at approximately 25 meters (before and after) at the beginning waste water collection and the other three points were selected by dividing the urban area into three regions (at the beginning, the middle and end of the collection points). For the effluent sample, there were selected five of the largest waste water samples (sewage) from the Poty River.

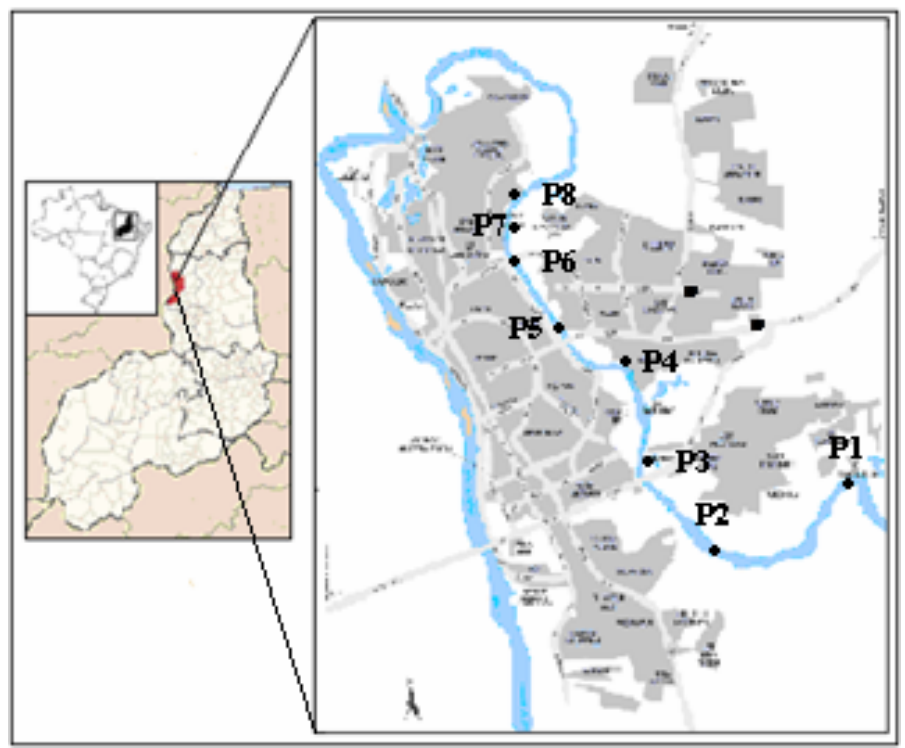

Fig 1. Poty River Map of sampling location in urban area of Teresina

Samples of water and effluents were collected (three samples to form a single composite sample) in polyethylene bottles and stored in a polystyrene box with ice. In the laboratory, they were filtered and preserved at $\pm 4{ }^{\circ} \mathrm{C}$ in a refrigerator until the time of analysis [18] The sediment samples ( $500 \mathrm{~g}$ ) were obtained by collecting four single samples (depth $0-10 \mathrm{~cm}$ ) to form a mixture of sample. All sediment samples were collected 
in a plastic cup and after they were sifted with a nylon sieve of $2 \mathrm{~mm}$ in diameter, dried in an oven for $5 \mathrm{~h}$ at a temperature of $65^{\circ} \mathrm{C}$. After drying, the pellet was pulverized in a porcelain mortar and sieved again in nylon sieve of $1 \mathrm{~mm}$ diameter [9,19]. These sediments were stored in plastic bags and stored at room temperature until the time of sample opening to quantify metals.

Table 1. Location of collection points and types of samples collected at each point.

\section{Results and discussion}

Given the great importance of the Poty River for the state of Piauí and its relevance to environmental preservation, it was necessary to monitor the same through different points. Some physical and chemical parameters and toxic metals in water and sediments

\begin{tabular}{cccc}
\hline \multirow{2}{*}{$\begin{array}{c}\text { Colletion } \\
\text { points }\end{array}$} & \multicolumn{2}{c}{ Location } & Types of samples \\
\cline { 2 - 3 } & \multicolumn{2}{c}{ Latitude } & \multicolumn{2}{c}{ Longitude } & \\
\hline P1 & $5^{\circ} 06^{\prime} 45.07^{\prime \prime} \mathrm{S}$ & $42^{\circ} 43^{\prime} 49.53^{\prime \prime} \mathrm{W}$ & Water (P1W) and Sediment (P1S) \\
P2 & $5^{\circ} 07^{\prime} 01.31^{\prime \prime} \mathrm{S}$ & $42^{\circ} 46^{\prime} 34.25^{\prime \prime} \mathrm{W}$ & Water (P2W), Sewer (P2E) and Sediment (P2S) \\
P3 & $5^{\circ} 05^{\prime} 20.72^{\prime \prime} \mathrm{S}$ & $42^{\circ} 47^{\prime} 06.96^{\prime \prime} \mathrm{W}$ & Water (P3W), Sewer (P3E) and Sediment (P3S) \\
P4 & $5^{\circ} 05^{\prime} 13.48^{\prime \prime} \mathrm{S}$ & $42^{\circ} 47^{\prime} 31.52^{\prime \prime} \mathrm{W}$ & Water (P4W) and Sediment (P4S) \\
P5 & $5^{\circ} 04^{\prime} 43.35^{\prime \prime} \mathrm{S}$ & $42^{\circ} 47^{\prime} 49.33^{\prime \prime} \mathrm{W}$ & Water (P5W), Sewer (P5E) and Sediment (P5S) \\
P6 & $5^{\circ} 04^{\prime} 30.04^{\prime \prime} \mathrm{S}$ & $42^{\circ} 47^{\prime} 59.32^{\prime \prime} \mathrm{W}$ & Water (P6W), Sewer (P6E) and Sediment (P6S) \\
P7 & $5^{\circ} 04^{\prime} 03.33^{\prime \prime} \mathrm{S}$ & $42^{\circ} 48^{\prime} 18.40^{\prime \prime} \mathrm{W}$ & Water (P7W), Sewer (P7E) and Sediment (P7S)
\end{tabular}

\section{Metals Extraction and recovery test}

$20 \mathrm{~mL} \mathrm{HNO}_{3}$ and $10 \mathrm{~mL} \mathrm{HClO}_{4}$ (concentrated) were added to $2 \mathrm{~g}$ of dry sediment. The mixture was heated in a digestor at $150{ }^{\circ} \mathrm{C}$ for $2 \mathrm{~h}$. After a brief cooling, $10 \mathrm{~mL}$ of $\mathrm{H}_{2} \mathrm{O}_{2}(30 \%)$ were added slowly [18] Then the solution was filtered and diluted to $50 \mathrm{~mL}$ with deionized water and analyzed in triplicate by atomic absorption spectroscopy.

The method accuracy tests were made by recovery (or recovery factor) of the analyte added in the sample. These studies consisted of samples fortified with known analyte concentrations at different levels, followed by extraction of the metals using the same methodology used to extract the metals in the original samples and subsequent determination of their concentration in spiked samples.

\section{Statistical Analysis}

The significance of data obtained in this study was verify by PCA - Principal Component Analysis using the Statistical Package for Social Sciences (SPSS) software and the graphics were constructed by Origin software. were analyzed as well as some effluents released in the Poty River. The samples were collected at the same point, during three periods, comprising in periods of dry and wet precipitation.

\section{Method Evaluation}

The recovery tests have provided values for $\mathrm{Pb}, \mathrm{Cr}, \mathrm{Ni}$ and $\mathrm{Cu}$ equal to $97.39,119.63,107.21$ and $113.93 \%$, respectively. The method showed satisfactory precision due to the results having been quite close together and the variation coefficients below 9\%. The acceptable range of recovery for residue analysis is usually between 70 and $120 \%$ and accurate to $\pm 20 \%$. However, depending on the complexity and analytical sample, this value can be 50 to $120 \%$ and accurate to \pm $15 \%$ [20]

The quantification limits obtained for this method in water and effluent samples were $0.117 \mathrm{mg}$ $\mathrm{L}^{-1}(\mathrm{~Pb}), 0.089 \mathrm{mg} \mathrm{L}^{-1}(\mathrm{Cr}), 0.042 \mathrm{mg} \mathrm{L}^{-1}(\mathrm{Ni}), 0.016 \mathrm{mg}$ $\mathrm{L}^{-1}(\mathrm{Cu})$. The quantification limits to sediments samples were $0.149 \mathrm{mg} \mathrm{L}^{-1}(\mathrm{~Pb}), 0.169 \mathrm{mg} \mathrm{L}^{-1}(\mathrm{Cr}), 0.056 \mathrm{mg} \mathrm{L}^{-1}$ (Ni) and $0.024 \mathrm{mg} \mathrm{L}^{-1}(\mathrm{Cu})$.

\section{Physical and chemical parameters}


CONAMA Resolution $n^{0} 357 / 05$ deals with the standards and criteria for water classification. Among the regulated variables are $\mathrm{pH}$, dissolved oxygen, nitrate and nitrite concentration, conductivity and temperature. These variables were evaluated in samples of water and waste water and the results can be seen in Table 2 .

Table 2. Physico-chemical parameters concerning three collections of water, $P x A,(x=1-8)$ and effluents, $P y E,(y=2-7)$.

\begin{tabular}{|c|c|c|c|c|c|c|}
\hline \multirow{2}{*}{$\begin{array}{l}\text { Colletion } \\
\text { points }\end{array}$} & \multicolumn{6}{|c|}{ Physico-chemical parameters } \\
\hline & $\mathrm{T}\left({ }^{\circ} \mathrm{C}\right)$ & $\mathrm{pH}$ & $\begin{array}{c}\mathrm{DO} \\
\left(\mathrm{mg} \mathrm{L}^{-1}\right)\end{array}$ & $\begin{array}{c}\mathrm{NO}_{3}^{-} \\
\left(\mathrm{mg} \mathrm{L}^{-1}\right)\end{array}$ & $\begin{array}{c}\mathrm{NO}_{2}^{-} \\
\left(\mathrm{mg} \mathrm{L}^{-1}\right)\end{array}$ & $\begin{array}{l}\text { conductivity } \\
\left(\mu \mathrm{S} \mathrm{cm}^{-1}\right)\end{array}$ \\
\hline P1Wa & 28.8 & 8.04 & 3.06 & 0.22 & 0.02 & 257.50 \\
\hline P1Wb & 30.3 & 7.18 & 3.75 & 4.48 & 0.03 & 131.30 \\
\hline $\mathrm{P} 1 \mathrm{Wc}$ & 30.0 & 6.61 & 5.60 & 5.95 & 0.10 & 43.12 \\
\hline P2Wa & 28.4 & 7.49 & 3.00 & 0.26 & 0.03 & 278.80 \\
\hline $\mathrm{P} 2 \mathrm{~Wb}$ & 30.2 & 7.33 & 3.43 & 0.53 & 0.01 & 140.50 \\
\hline $\mathrm{P} 2 \mathrm{Wc}$ & 31.1 & 6.80 & 2.50 & 2.41 & 0.03 & 72.70 \\
\hline P3Wa & 27.1 & 7.41 & 3.75 & 0.70 & 0.02 & 314.80 \\
\hline $\mathrm{P} 3 \mathrm{~Wb}$ & 28.5 & 7.26 & 4.35 & 0.59 & 0.01 & 152.80 \\
\hline P3Wc & 27.6 & 6.81 & 4.60 & 0.28 & 0.18 & 74.58 \\
\hline P4Wa & 29.8 & 7.63 & 4.00 & 0.17 & 0.10 & 299.70 \\
\hline $\mathrm{P} 4 \mathrm{~Wb}$ & 30.8 & 7.38 & 4.12 & 18.01 & 0.01 & 196.60 \\
\hline P4Wc & 27.4 & 7.02 & 4.80 & 0.30 & 0.18 & 72.70 \\
\hline P5Wa & 27.1 & 7.32 & 3.85 & 0.79 & 0.13 & 325.10 \\
\hline P5Wb & 31.0 & 7.46 & 4.15 & 1.53 & 0.02 & 169.20 \\
\hline P5Wc & 27.3 & 6.81 & 5.00 & 0.32 & 0.18 & 84.00 \\
\hline P6Wa & 27.9 & 7.38 & 3.95 & 0.23 & 0.04 & 314.00 \\
\hline $\mathrm{P} 6 \mathrm{~Wb}$ & 28.3 & 7.18 & 4.45 & 8.17 & 0.08 & 190.10 \\
\hline P6Wc & 27.5 & 6.97 & 3.00 & 0.30 & 0.19 & 89.67 \\
\hline P7Wa & 27.3 & 7.54 & 3.35 & 0.53 & 0.07 & 464.30 \\
\hline P7Wb & 29.6 & 7.30 & 3.85 & 97.54 & 0.07 & 603.70 \\
\hline P7Wc & 28.2 & 7.26 & 5.60 & 0.52 & 0.11 & 320.00 \\
\hline P8Wa & 28.1 & 7.52 & 3.45 & 0.17 & 0.10 & 303.40 \\
\hline P8Wb & 29.0 & 7.24 & 4.35 & 0.50 & 2.44 & 159.50 \\
\hline P8Wc & 27.7 & 6.86 & 4.70 & 0.67 & 0.31 & 129.00 \\
\hline P2Ea & 26.2 & 7.47 & 1.96 & 0.91 & 0.11 & 482.10 \\
\hline $\mathrm{P} 2 \mathrm{~Eb}$ & 29.0 & 7.26 & 2.55 & 21.86 & 38.65 & 532.50 \\
\hline $\mathrm{P} 2 \mathrm{Ec}$ & 29.1 & 7.15 & 1.00 & 0.30 & 0.05 & 505.40 \\
\hline P3Ea & 27.7 & 7.49 & 2.83 & 1.08 & 0.19 & 699.20 \\
\hline $\mathrm{P} 3 \mathrm{~Eb}$ & 30.1 & 6.90 & 2.97 & 3.04 & 0.01 & 532.50 \\
\hline P3Ec & 28.4 & 7.11 & 1.70 & 0.11 & 0.13 & 505.40 \\
\hline P5Ea & 26.3 & 7.15 & 2.90 & 2.45 & 0.19 & 587.40 \\
\hline $\mathrm{P} 5 \mathrm{~Eb}$ & 28.8 & 7.16 & 2.55 & 9.80 & 3.77 & 516.60 \\
\hline P5Ec & 27.2 & 7.27 & 5.90 & 1.14 & 0.10 & 431.90 \\
\hline P6Ea & 26.3 & 7.06 & 1.96 & 0.22 & 0.20 & 486.00 \\
\hline $\mathrm{P} 6 \mathrm{~Eb}$ & 30.1 & 6.42 & 1.37 & 5.57 & 0.02 & 574.70 \\
\hline P6Ec & 30.4 & 6.91 & 2.50 & 0.35 & 0.08 & 504.70 \\
\hline P7Ea & 22.7 & 7.64 & 2.36 & 3.14 & 0.22 & 612.30 \\
\hline $\mathrm{P} 7 \mathrm{~Eb}$ & 29.7 & 7.62 & 2.78 & 79.94 & 0.24 & 628.40 \\
\hline P7Ec & 28.6 & 7.35 & 5.60 & 0.27 & 0.08 & 536.30 \\
\hline
\end{tabular}

${ }^{2}$ first collection, ${ }^{b}$ second collection end $c_{\text {third }}$ collection 
Both effluent samples and water samples met the CONAMA Resolution 357/05, which allows variations in $\mathrm{pH}$ between 5 and 9 for effluents and 6 and 9 for fresh water.

The $\mathrm{pH}$ measurements in water samples ranged between 6.6 and 8.0, and they are within the range considered tolerable by law. The value of $\mathrm{pH}$ of the point 1 sample has presented the largest at collection in the first collection, which was unexpected, since according to the Nautical Chart of the Parnaíba and Poty rivers (2002) there is no record of effluent discharges above those points that are able to make an amendment to increase the quality of that water. However, as this is a place used for entertainment, with bars and restaurants, it is probable that human actions are the main reason for this variation in $\mathrm{pH}$ value.

In the third collection, which corresponds to the rainy season, the water had the lowest $\mathrm{pH}$ values. This fact can be influenced by heavy rain and runoff causing a higher stroke of open sewers that are released in the soil of neighborhoods near the river. The heavy rain and runoff can promote the accumulation of garbage in the streets and storm drains in the long period of drought. The dilution factor must also be considered, because in this period (March) the river had the highest volume of water during the collections.

Regarding conductivity, only the samples of the third collection (in March) in the points 1-7 did not show values above that permitted by law, which considers freshwater environments impacted when presenting levels above $100 \mathrm{mS} \mathrm{cm}^{-1}$ (CETESB, 2009 ) [21].

The results also suggest that the effluents discharge into the Poty River is a punctual source of pollution, with conductivity 3 to 6 times higher than the values found for water samples. The effluents can be considered as the main factors for increasing the electrical conductivity of water bodies. The greatest results for conductivity in the water were found in the non-rain period.

In relation to temperature, the current legislation refers only to conditions and standards for effluent discharge. In accordance to CONAMA Resolution $397 / 08$, the temperature of discharge should be below $40{ }^{\circ} \mathrm{C}$, while the variation of the receiving body must not exceed $3{ }^{\circ} \mathrm{C}$ at the edge of the mixing zone. All temperatures measured were within limits considered safe for the legislation. These values are characteristic of domestic sewage, which do not use heating as the industries.

The measures of dissolved oxygen (DO) were performed in triplicate with standard deviation ranging from \pm 0.06 to \pm 0.23 . The results found in most water samples showed values outside the recommended legislation that establishes values greater than $4 \mathrm{mg} \mathrm{L}^{-1}$ to waters Class 3.

In the third and fourth collections, some samples showed an increase in the concentration of dissolved oxygen with values greater than $5 \mathrm{mg} \mathrm{L}^{-1}$ (value established for water class 2) [22], which may be related to the precipitation of rain in that period.

The effluent samples showed low values of DO, throughout the period of study, which was expected due to the strong presence of organic matter (food scraps, dead animals, etc.), that was clearly observed in the effluent samples, and also by the proliferation of water hyacinth (Eichornia crassipes) near the effluent. Even the samples of effluent coming from the treatment plant, $\mathrm{P}_{7} \mathrm{E}$ presented low values of $\mathrm{DO}$. The first two collections were made in the hottest period of the year, and high temperatures can be contributed to the low DO concentrations found in these water samples [22].

Table 2 shows the physico-chemical parameters and the results to $\mathrm{NO}_{3}{ }^{-}$we can highlight the $\mathrm{P}_{7}$ point of the second collection that has a concentration equal to $97.54 \mathrm{mg} \mathrm{L}^{-1}$, due to this concentration being more than nine times the value permitted by CONAMA resolution 357/05 [25].

The point P7 is located below the discharge of the effluent analyzed in this study that receives treatment by the water and sewage treatment company of Piaui. The effluent is subjected to aeration treatment, which oxidizes $\mathrm{NO}_{2}^{-}$to $\mathrm{NO}_{3}^{-}$, and in the $\mathrm{P} 7 \mathrm{E}$ point the concentration found to $\mathrm{NO}_{3}^{-}$was $79.94 \mathrm{mg} \mathrm{L}^{-1}$, and this concentration may be contributing to the high nitrate concentration in the $\mathrm{P}_{7}$ point.

With respect to $\mathrm{NO}_{2}^{-}$, all water samples meet the planned legislation [22] $\left(1 \mathrm{mg} \mathrm{L}^{-1}\right)$ for fresh water. In relation to the effluent, the quantity found of $\mathrm{NO}_{2}{ }^{-}$at the P2E (second collection) was $38.65 \mathrm{mg} \mathrm{L}^{-1}$. This concentration was expected, because high nitrite concentrations are evidence of domestic effluent release and decomposition of organic matter, so at this point a large release of organic matter (food scraps, dead animals, etc.) was observed.

Metals Analysis in samples of effluents, water and sediments collected in Poty River

The metals are considered as one of the most 
common contaminants in water and their origin can be anthropic or natural $[2,10,16]$. The anthropogenic origin of metals can come from many contamination sources, such as effluents from recycling workshops of automobile engines and industries [2].

This study analyzed the concentrations of metals such as, $\mathrm{Pb}, \mathrm{Ni}, \mathrm{Cu}$ and $\mathrm{Cr}$, found in water, wastewater and sludge from the Poty River. These results were correlated with another study done in sewage from automatic grinds, which throw the waste into the bed of the Poty River, without any prior purification [2].

Fig. 2 shows the metals analyzed and the results found are below that which is permitted by CONAMA resolution 357/05. $\mathrm{Cr}$ analysis was below the equipment quantification limit. These concentrations of metals found in the waters of the Poty River, according to CONAMA resolution, do not classify them as classes 1 , 2 and 3. In other words, these waters can not be used for direct recreational use, neither for irrigation to vegetables that are eaten raw without removal of film. Finally, these waters are not suitable to any kind of primary contact before any pre-treatment.

The highest metal concentrations found were the samples collected in December (early rains). This fact may be related to the large amount of accumulated waste in the vicinity of the Poty River and are drawn with the rain into the river. The $\mathrm{Pb}$ concentration in water samples was increased from $\mathrm{P} 1$ to $\mathrm{P} 8$ ranging from 0.30 $\mathrm{mg} \mathrm{L}^{-1}(\mathrm{P} 1)$ to $0.86 \mathrm{mg} \mathrm{L}^{-1}$ (P8). This increase occurs as the water river receives effluent discharges, and this fact can be called "the summation effect". This same effect was not observed in $\mathrm{Cu}$ and $\mathrm{Ni}$ concentrations, and it's showing that the concentrations of these metals do not change significantly over the Teresina urban area.

The results of metal analysis performed in the effluent samples showed that concentrations of $\mathrm{Cu}, \mathrm{Ni}$ and $\mathrm{Cr}$ are lower than permitted by CONAMA Resolution $357 / 05$. These results show that these metals concentrations will not cause toxicities to aquatic organisms present in the Poty River. However, concentrations of $\mathrm{Pb}$ from effluent collections made in December, the beginning of the rainy season in Teresina, present concentrations up to 2.4 times above the maximum allowable, thus corroborating with the results found in water samples collected in the same period. These high concentrations of $\mathrm{Pb}$ found in the samples collected in December indicate that various types of domestic refuse and/or industrial areas containing lead in their composition are being disposed of in an irregular way and may cause environmental and pathological damage [23]. (a)

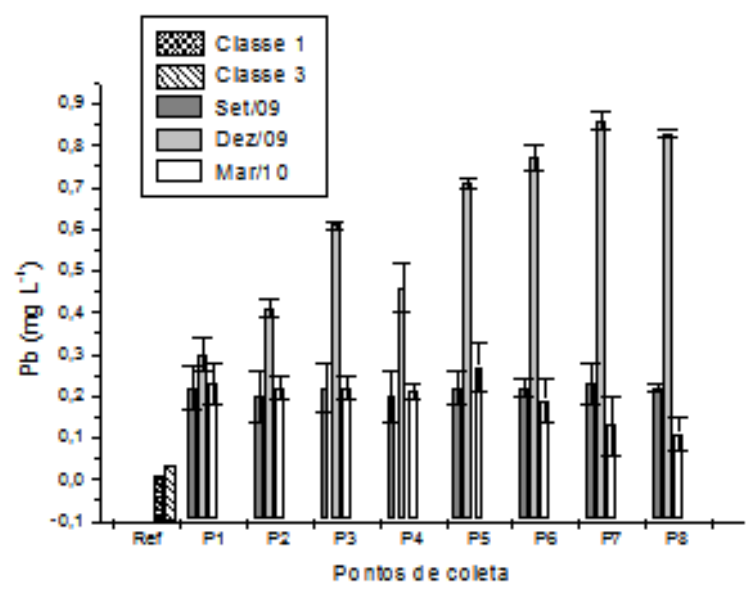

(b)

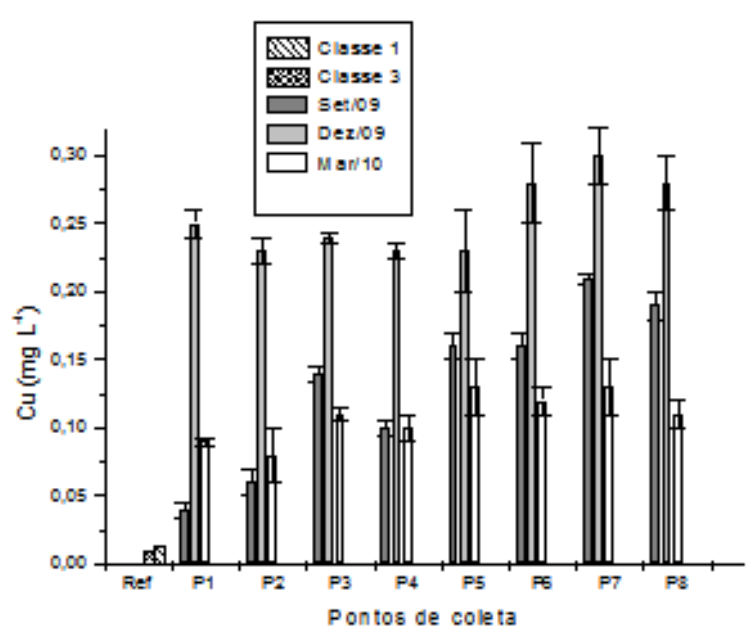

(c)

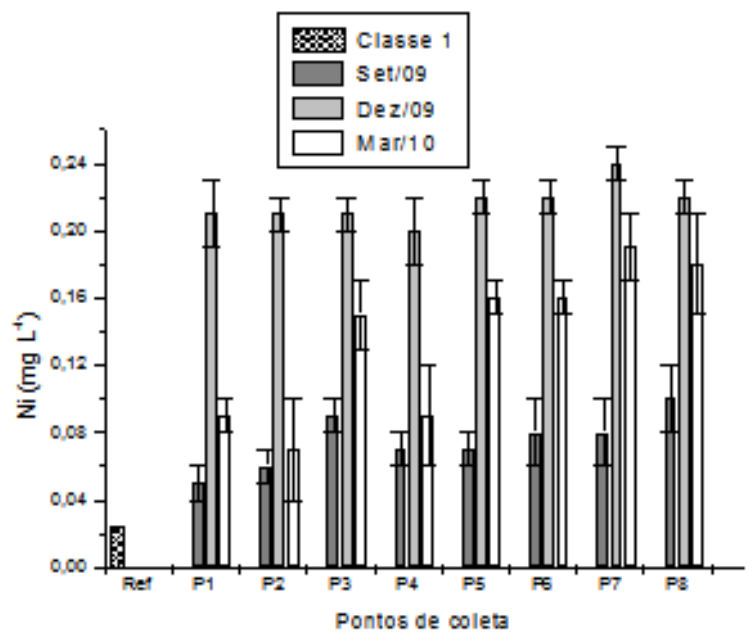

Fig. 2. Concentrations of $\mathrm{Pb}(\mathrm{a}), \mathrm{Cu}(\mathrm{b})$ and $\mathrm{Ni}(\mathrm{C})$ in water samples, compared to the levels permitted by the Resolution 357/05 of CONAMA to waters of classes 1 and 3 . 
In general, metal concentrations analyzed in sediments, Table 3, collected in the Poty River, were below the limit of quality established by the Company of Environmental Sanitation Technology (CETESB) [24], except for $\mathrm{Pb}$ and $\mathrm{Ni}$, both collections $\mathrm{P} 6 \mathrm{~S}$ point. It is noteworthy that this collection point is close to a large gallery that receives waste, without any prior treatment, from a variety of sources including a hospital.

Table 3. Concentrations of $\mathrm{Pb}, \mathrm{Cu}, \mathrm{Ni}$ and $\mathrm{Cr}$ in effluent samples (in mg L-1) and sediment (mg kg-1) ( $\mathrm{n}=3$ ) in the urban area of Teresina.

\begin{tabular}{|c|c|c|c|c|c|}
\hline \multirow{2}{*}{\multicolumn{2}{|c|}{ Samples / Acronyms }} & \multicolumn{4}{|c|}{ Metals } \\
\hline & & $\mathrm{Pb}$ & $\mathrm{Cu}$ & $\mathrm{Ni}$ & $\mathrm{Cr}_{\mathrm{r}}$ \\
\hline \multirow{15}{*}{ Efluentes/ } & P2E & $0.18 \pm 0.03$ & $0.14 \pm 0.04$ & $0.12 \pm 0.02$ & $<\mathrm{LD}$ \\
\hline & P2Es & $0.99 \pm 0.02$ & $0.32 \pm 0.01$ & $0.22 \pm 0.07$ & $<\mathrm{LD}$ \\
\hline & P2Et & $0.15 \pm 0.01$ & $0.21 \pm 0.02$ & $0.24 \pm 0.02$ & $<\mathrm{LD}$ \\
\hline & P3Ep & $0.18 \pm 0.01$ & $0.15 \pm 0.01$ & $0.14 \pm 0.02$ & $<\mathrm{LD}$ \\
\hline & P3Es & $0.98 \pm 0.03$ & $0.36 \pm 0.02$ & $0.23 \pm 0.04$ & $<\mathrm{LD}$ \\
\hline & P3Et & $0.16 \pm 0.02$ & $0.24 \pm 0.02$ & $0.26 \pm 0.02$ & $<\mathrm{LD}$ \\
\hline & $\overline{\mathrm{P} 5 \mathrm{E}_{\mathrm{p}}}$ & $0.15 \pm 0.01$ & $0.16 \pm 0.01$ & $0.14 \pm 0.01$ & $<\mathrm{LD}$ \\
\hline & P5Es & $1.07 \pm 0.04$ & $0.37 \pm 0.02$ & $0.27 \pm 0.01$ & $<\mathrm{LD}$ \\
\hline & P5Et & $0.16 \pm 0.02$ & $0.25 \pm 0.00$ & $0.26 \pm 0.01$ & $<\mathrm{LD}$ \\
\hline & $\mathrm{P} 6 \mathrm{E}_{\mathrm{p}}$ & $0.19 \pm 0.03$ & $0.14 \pm 0.01$ & $0.13 \pm 0.01$ & $<\mathrm{LD}$ \\
\hline & P6Es & $1.08 \pm 0.04$ & $0.33 \pm 0.01$ & $0.24 \pm 0.04$ & $<\mathrm{LD}$ \\
\hline & P6Et & $0.10 \pm 0.02$ & $0.24 \pm 0.00$ & $0.26 \pm 0.03$ & $<\mathrm{LD}$ \\
\hline & $\mathrm{P} 7 \mathrm{E}_{\mathrm{p}}$ & $0.17 \pm 0.02$ & $0.17 \pm 0.01$ & $0.14 \pm 0.01$ & $<\mathrm{LD}$ \\
\hline & P7Es & $1.20 \pm 0.01$ & $0.38 \pm 0.02$ & $0.29 \pm 0.02$ & $<\mathrm{LD}$ \\
\hline & P7Et & $0.15 \pm 0.02$ & $0.24 \pm 0.02$ & $0.26 \pm 0.01$ & $<\mathrm{LD}$ \\
\hline \multirow{24}{*}{ Sedimentos/ } & $\mathrm{P} 1 \mathrm{~S}_{\mathrm{p}}$ & $4.75 \pm 0.25 \mathrm{e}$ & $5.68 \pm 0.14$ & $1.57 \pm 0.51$ & $3.31 \pm 0.28$ \\
\hline & P1Ss & $4.92 \pm 0.63$ & $5.04 \pm 0.81$ & $3.35 \pm 0.52$ & $4.15 \pm 0.16$ \\
\hline & P1St & $9.75 \pm 0.75$ & $22.27 \pm 1.67$ & $10.48 \pm 0.43$ & $18.94 \pm 0.83$ \\
\hline & $\mathrm{P} 2 \mathrm{~S}_{\mathrm{f}}$ & $8.42 \pm 0.38$ & $8.01 \pm 0.86$ & $1.59 \pm 0.71$ & $4.40 \pm 0.25$ \\
\hline & P2Ss & $12.83 \pm 1.01$ & $12.63 \pm 1.18$ & $14.12 \pm 1.96$ & $13.40 \pm 0.82$ \\
\hline & P2St & $7.58 \pm 0.38$ & $7.14 \pm 0.41$ & $2.38 \pm 0.38$ & $4.95 \pm 0.19$ \\
\hline & P3 $\mathrm{S}_{\mathrm{f}}$ & $9.83 \pm 1.66$ & $8.78 \pm 0.34$ & $2.37 \pm 0.14$ & $10.99 \pm 1.53$ \\
\hline & P3Ss & $13.75 \pm 1.09$ & $12.37 \pm 1.14$ & $12.69 \pm 1.02$ & $15.77 \pm 0.31$ \\
\hline & P3St & $15.17 \pm 2.08$ & $10.01 \pm 0.49$ & $4.46 \pm 0.22$ & $12.04 \pm 0.65$ \\
\hline & $\mathrm{P} 4 \mathrm{~S}_{\mathrm{p}}$ & $4.25 \pm 0.25$ & $6.05 \pm 0.48$ & $1.20 \pm 0.42$ & $2.67 \pm 0.14$ \\
\hline & P4Ss & $7.92 \pm 0.63$ & $5.57 \pm 0.57$ & $6.49 \pm 0.58$ & $7.12 \pm 0.29$ \\
\hline & P4St & $9.50 \pm 1.95$ & $10.18 \pm 0.63$ & $4.99 \pm 0.71$ & $10.06 \pm 0.52$ \\
\hline & P5S & $7.00 \pm 1.50$ & $5.14 \pm 0.41$ & $0.82 \pm 0.23$ & $6.17 \pm 1.53$ \\
\hline & P5Ss & $10.67 \pm 0.58$ & $8.00 \pm 1.29$ & $9.69 \pm 0.59$ & $12.25 \pm 0.78$ \\
\hline & P5St & $15.33 \pm 0.38$ & $17.48 \pm 1.13$ & $9.34 \pm 0.08$ & $17.35 \pm 0.20$ \\
\hline & $\mathrm{P} 6 \mathrm{~S}_{\mathrm{p}}$ & $7.67 \pm 1.01$ & $8.43 \pm 0.00$ & $2.59 \pm 0.44$ & $7.17 \pm 1.15$ \\
\hline & P6Ss & $19.42 \pm 1.42$ & $19.37 \pm 0.73$ & $24.14 \pm 0.72$ & $18.42 \pm 0.31$ \\
\hline & P6St & $18.58 \pm 3.19$ & $15.05 \pm 1.53$ & $7.89 \pm 0.55$ & $18.23 \pm 1.64$ \\
\hline & P7 $\mathrm{S}_{\mathrm{p}}$ & $5.25 \pm 0.50$ & $5.23 \pm 0.41$ & $0.29 \pm 0.12$ & $2.25 \pm 0.51$ \\
\hline & P7Ss & $8.58 \pm 1.89$ & $4.00 \pm 0.67$ & $7.68 \pm 0.99$ & $6.43 \pm 0.10$ \\
\hline & P7St & $13.25 \pm 0.00$ & $11.01 \pm 0.19$ & $5.90 \pm 0.33$ & $12.08 \pm 0.16$ \\
\hline & P8S & $9.58 \pm 2.27$ & $6.78 \pm 0.37$ & $1.17 \pm 0.51$ & $7.05 \pm 1.07$ \\
\hline & P8Ss & $11.00 \pm 0.50$ & $4.42 \pm 0.24$ & $7.34 \pm 0.73$ & $1.17 \pm 0.09$ \\
\hline & P8St & $16.08 \pm 3.74$ & $8.28 \pm 1.73$ & $2.45 \pm 0.16$ & $8.84 \pm 0.55$ \\
\hline
\end{tabular}




\section{Principal Component Analysis (PCA)}

The Principal Component Analysis (PCA) was done using a correlation matrix for 63 samples (water $=$ 24 , effluent $=15$ and sediment $=24$ ) with four variables $(\mathrm{Pb}, \mathrm{Cu}, \mathrm{Ni}$ and $\mathrm{Cr})$. The variability of the samples was synthesized in four main components as shown in Figure 3. The first of these components (PC1) summarized $90.89 \%$ of the original information and the second one (PC2) summarized $5.80 \%$. The other two major components were considered variance residue because they presented a variance below then $10 \%$. The first and the second components explained $96.69 \%$ of the data variability $[25,26]$.

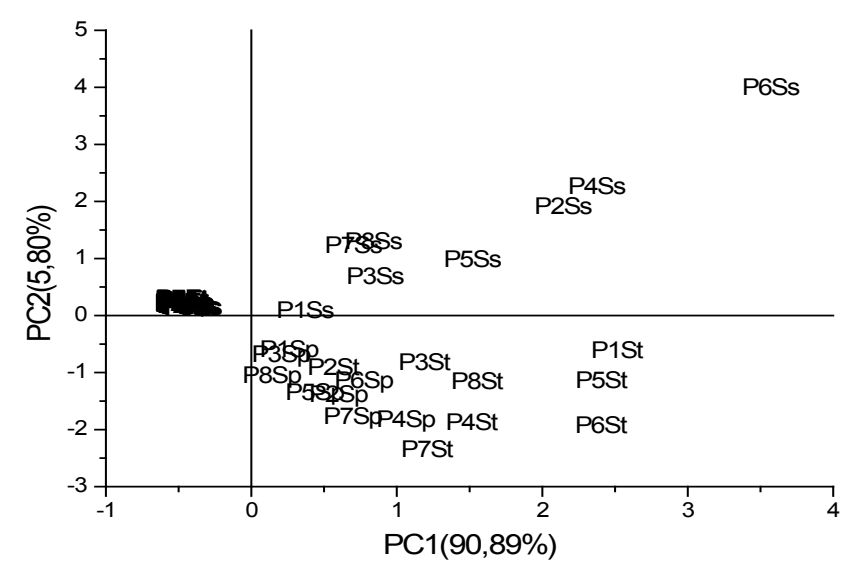

Fig. 3. Biplot diagram of scores and weights considering the first and the second main components of the 63 samples.

Water and effluent samples were superimposed on the left of the PC1, indicating a strong correlation between them. The sediment samples (P1S to P8S) stood out to the right of that component, being separated into three groups according to the time of collection (period of low or high wet precipitation). The sediment samples were placed in the positive of PC1 component, and they showed strong correlation with the metals analyzed. In addition, we can observe a clear grouping separation of the samples, in accordance to the collection period.

Samples collected in December (period of low wet precipitation- P1Ss-P7Ss samples) were above the horizontal line, while those samples collected in September (period without wet precipitation-P1S $-\mathrm{P} 7 \mathrm{~S}_{\mathrm{p}}$ samples) and March (period of large precipitation rainy P1St-P7St samples), stood below the horizontal line. These results show a strong correlation between the metal concentrations and the period of the collections. Samples of the second collection also correlated with the second principal component, due to high concentrations of the Ni found in these samples.

Due the low levels of $\mathrm{Pb}, \mathrm{Cu}, \mathrm{Ni}$ and $\mathrm{Cr}$, the first samples collections (collected in September) were located near the vertical axis of PC1, indicating a weak correlation with the same.

The samples collected in September and March were not correlated due to their location in the negative part of the component PC2 and possibly being influenced by low Ni concentration.

The samples of sediment that were collected during the rainy season (March) predominated the finest fractions (silt clay) which concentrate the highest levels of metals, because this also contributes to higher concentrations during this period. Furthermore, the metals can also be transported from remote locations because the flow rate of water is higher.

When we analyze the results shown in Figure 3 , we can observe a strong correlation between samples of water and waste water. Thus, we make a study of PCA to those samples in order to investigate correlations between them (Fig. 4).

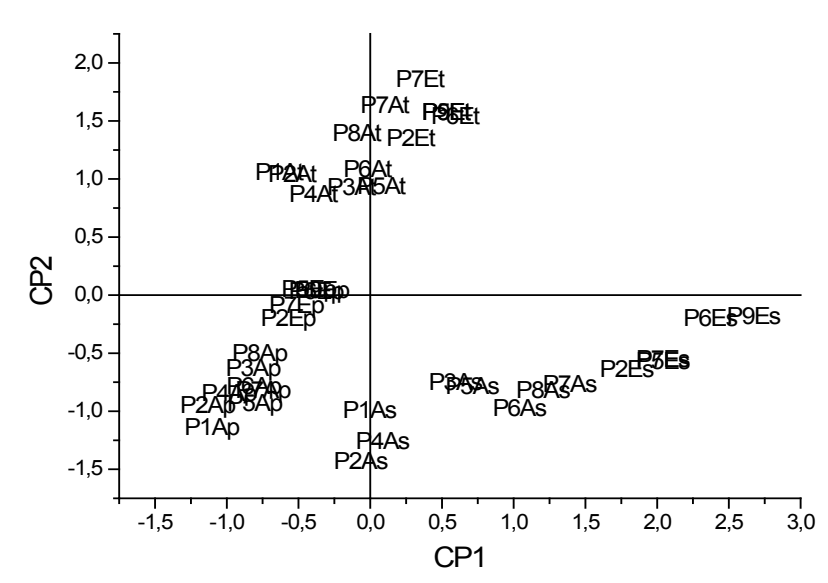

Fig. 4. Biplot graphical of scores and weights (loading) for the first two principal components for 24 samples of water and 15 sewers

The samples were separated into three groups depending on the season, because the groups are formed for drought periods (no rain precipitation) and wet periods. The group relative to the first collection (September) includes samples of the dry period where the river is subject to pollution sources due to effluents from Teresina. The samples of the second collection (December) stood out in another group, that corresponding the beginning of the rainy season, with some rainfall, add- 
ing to the point sources, diffuse sources such as soils contaminated by metals and trash from the streets and ditches.

This increase is maintained until the third gathering, held in March, the month in which the river has received large amounts of pollutants due to the heavy rainfall that happens in this period.

The metal concentrations in effluents analyzed presented near or above their concentration in samples of river water. Therefore, it is possible to suggest that the effluents are contributing significantly to the contamination of the Poty River with metals such as $\mathrm{Pb}$, $\mathrm{Ni}$ and $\mathrm{Cu}$. The study also showed that during the rainy season there is a greater contamination of the river due to the drag garbage brought by the floods accumulated on the streets during the long dry period.

Another study conducted in urban soils in the Teresina city revealed concentrations of toxic metals in eight points (gardens and avenues) near the Poty River [13]. These soils probably are carted to the River during the rainy season.

\section{Conclusion}

The results of some physico-chemical parameters showed that the water of the Poty River in the urban area of Teresina is unsuitable for activities such as direct recreational usage, irrigation of vegetables and fruits that are consumed without removal of film. The results obtained in effluent samples showed that concentrations of $\mathrm{Cu}, \mathrm{Ni}$ and $\mathrm{Cr}$ are below the standards established by CETESB. However, $\mathrm{Pb}$ concentrations in samples collected at the beginning of the rainy season, showed above the maximum established by CETESB, reaching a concentration of $1.20 \mathrm{mg} \mathrm{L}^{-1}$ in the effluent P7E, descendant to AGESPISA treatment plant. P7E point also presented the highest concentration of $\mathrm{NO}_{3}^{-}$in the samples collected in the same period. Furthermore, the effluent (P7E) presented the highest molar conductivity in all samples, ie, showing that the treatment carried out by AGESPISA is not being efficient in the removal of dissolved inorganic substances. In general, the metal concentrations analyzed in sediments are within the range considered as reference quality by CETESB. In its view, such values do not present a danger of harmful effects to organisms. PCA statistical analysis of the results obtained in this study showed the effects of seasonality, as the metal concentrations were higher in the period of heaviest rainfall due to diffuse sources of pollution displaced by the floods discharged into the Poty River.

\section{Acknowledgment}

The authors thank the following Brazilian agencies: Coordenacão de Aperfeicoamento de Pessoal de Nível Superior (CAPES), Conselho Nacional de Desenvolvimento Científico e Tecnológico (CNPq), Financiadora de Estudos e Projetos (FINEP), and Fundação de Amparo a Pesquisa do Estado do Piauí (FAPEPI), for their financial support.

\section{References}

[1] R. Cassidy, P. Jordan, Limitations of instantaneous water quality sampling in surface-water catchments: Comparison with near-continuous phosphorus time-series data. J. Hydrol. 405 (2011) 182-195.

[2] E.L.C. Silveira, L.B. Caland, C.V.R. de Moura, E.M. de Moura, Determinação de contaminantes em óleos lubrificantes usados e em esgotos contaminados por esses lubrificantes, Quím. Nova 29 (2006) 1193 - 1197.

[3] F.Weigold, M. Baborowski, Consequences of delayed mixing for quality assessment of river water: Example Mulde-Saale-Elbe, J. Hydrol. 369 (2009) 296304.

[4] J.A. Baig, T.G. Kazi, M.B.Arain, H.I.Afridi, G.A.Kandhro, R.A.Sarfraz, M.K.Jamal, A.Q. Shah, Evalluation of arsenic and other physico-chenical parameters of surface and graund water of jamshoro, Pakistan, J. Hazard. Mater. 166 (2009), 662-669.

[5] A. Gómez-Alvarez, D. Meza-Figueroza, A.I. Villalba-Atondo, J.L. Valenzuela-García, J. Ramírez-Hernández, J. Almendariz-Tapia, Estimation of potential pollution from mine tailings in the San Pedro River (1993-2005), Mexico-US border, Environ. Geol 57 (2009) 1469-1479.

[6] Zhang, M.; Cui, L.; Sheng, L.; Wang, Y. Distribution and enrichment of heavy metals among sediments, water body and plants in HengshuihuWetland of Northern China, Ecological Engineering 35 (2009) 563-569.

[7] Santana, G. P.Santana, P.S.R. Barroncas, Estudo de metais pesados ( $\mathrm{Co}, \mathrm{Cu}, \mathrm{Fe}, \mathrm{Cr}, \mathrm{Ni}, \mathrm{Mn}, \mathrm{Pb}$ e $\mathrm{Zn}$ ) na Bacia do Tarumã-Açu Manaus - (AM), Acta Amazônica 37 (2007), 111-118.

[8] G.W. Siqueira, S.F.P. Pereira, F.M. Aprile, Determinação dos elementos-traço (Zn, Co e Ni) em sedimentos da Plataforma Continental Amazônica sob influência da descarga do rio Amazonas, Acta Amazônica 36 (2006), 321-326. 
[9] H.C. Jesus, E.A. Costa, A.S.F. Mendonça, E. Zandonade, Distribuição de metais pesados em sedimentos do sistema estuarino da Ilha de Vitória-ES, Quím. Nova 27 (2004), 378-386.

[10] J.S. Santos, J. S. M.L.P. dos Santos, E. Oliveira, Estudo da mobilização de metais e elementos traços em ambientes aquáticos do semi-árido brasileiro aplicando análises de componentes principais, Quím. Nova 31 (2008), 1107-1111.

[11] F. Wang, A.O.W. Leung, S.C. Wu, M.S. Yang, M.H. Wong, Chemical and ecotoxicological analyses of sediments and elutriates of contaminated rivers due to e-waste recycling activities using a diverse battery of bioassays, Environ. Pollut. 157 (2009) 2082-2090.

[12] V.V. Bogatov, L.V. Bogatova, Heavy metal accumulation by freshwater hydrobionts in a mining area in the south of the Russian far east, Russ. J. Ecol. 40 (2009) 187-193.

[13] M.C.S. Moura, A.N.C. Lopes, G.C. Moita, J.M.M Neto, Estudo multivariado de solos urbanos da cidade de Teresina, Quim. Nova 29 (2009), 429-435.

[14] A.V. Filgueiras, I. Lavilla, C. Bendicho, Evaluation of distribution, mobility and binding behaviour of heavy metals in surficial sediments of Louro River (Galicia, Spain) using chemometric analysis: a case study, Sci. Total Environ 330 (2004) 115-129.

[15] http://www.mp.pi.gov.br/meioambiente/documentos/category/69-modelos, accessed in february 2012.

[16] C.M. Zimmermann, O.M. Guimarães, P.G. Peralta-Zamora, Avaliação da qualidade do corpo hídrico do rio tibagi na região de ponta grossa utilizando análise de componentes principais (PCA), Quím. Nova 31 (2008) 1727-1732.

[17] Apha.; AWWA.; WPCF.; Standard Methods for the examination of Water and Wastewater, 17th ed., Washington, 1989.

[18] E. M. Richter, A. Fornaro, C.L. Lago L.; Angnes, Avaliação da composição química de águas do sistema guarapiranga: estudo de caso nos anos de 2002 e 2003, Quim. Nova 30 (2007), 1147-1152.

[19] J.J. Corbi, S.T. Strixino, A. Santos, M. Del Grande, Environmental diagnostic of metals and organochlorated compounds in streams near sugar cane plantations activity (State of São Paulo, Brazil) Quim. Nova 29 (2009), 61-65.

[20] M. Ribani, C.B.G. Bottoli, C.H. Collins, I.C.S.F. Jardim, L.F.C. Melo, Validação em métodos cromatográficos e eletroforéticos, Quim. Nova 27 (2004), 771780

[21] http://www.cetesb.sp.gov.br/Agua/rios/variaveis. asp, accessed in February 2012.

[22]http://www.aesa.pb.gov.br/legislacao/resolucoes/ conama/357_05_classificacao_corpos_agua.pdf, accessed in February 2012.

[23] Baird, C.; Química Ambiental, 2 ed., Bookman: Porto Alegre, 2002. Azevedo, F. A.; Chasin, A. A. M.; Metais: Gerenciamento da Toxicidade, Atheneu: São Paulo, 2003.

[24] http://www.cetesb.sp.gov.br/Agua/rios/publicacoes.asp, accessed in February 2012.

[25] M.A. Hortellani, J.E.S. Sarkis, D.M.S. Abessa, E.C.P.M. Sousa, Avaliação da contaminação por elementos metálicos dos sedimentos do Estuário Santos, Quim. Nova 31 (2008) 10-19

[26] E.A. Nonato, Z.G.G.Viola, K.C.B. Almeida, H.H.R. Schor, Tratamento estatístico dos parâmetros da qualidade das águas da bacia do Alto Curso do Rio das Velhas, Quim. Nova 30 (2007), 797-804. 